\title{
Molecular identification and phylogenetic analysis of Chlorella isolates from Indonesia using $r b c L$ gene
}

Identifikasi molekuler dan analisis kekerabatan isolat-isolat Chlorella dari Indonesia menggunakan gen rbcL

Fauziatul FITRIYAH*), Yora FARAMITHA, Dini Astika SARI, Irma KRESNAWATY, Tri PANJI, \& Djoko SANTOSO

Indonesian Research Institute for Biotechnology and Bioindustry, Jl. Taman Kencana No.1, Bogor 16128, Indonesia

Received 10 December 2020 / Accepted 27 April 2021

\begin{abstract}
Abstrak
Identifikasi spesies memegang peranan penting dalam penyusunan database yang mumpuni baik untuk mendukung aplikasi dalam bidang bioteknologi maupun untuk kepentingan komersial. Identifikasi secara morfologi tidak mampu memberikan deskripsi yang cukup terutama untuk mikroalga uniseluler yang berukuran kecil. Gen rbcL yang menyandikan large unit of ribulose-1, 5-bisphosphate carboxylase/oxygenase (Rubisco) telah banyak digunakan dalam barcoding tanaman dan sedang dikembangkan untuk identifikasi mikroalga secara molekuler. Dalam penelitian ini dilakukan identifikasi terhadap strain mikroalga hijau lokal asal Indonesia menggunakan marka barcoding rbcL. Mikroalga hijau yang diperoleh dari Yogyakarta, Serayu, Gondol, Ancol, Cilegon, dan Teluk Jakarta ditumbuhkan pada media f/2 kemudian dipanen untuk ekstraksi DNA. DNA yang diperoleh kemudian diamplifikasi dengan primer 1AB_rbcL dengan ukuran pita target 615 $b p$, dan dilakukan sequencing. Barcoding isolat DNA mikroalga hijau lokal telah berhasil dilakukan menggunakan pasangan primer 1AB_rbcL dengan kesamaan genetik mencapai 99\% terhadap spesies dalam database Genbank. Dari enam isolat, TJ, $G, S, C$, dan A teridentifikasi sebagai C. pyrenoidosa. Hanya isolat $C P$ dari Yogyakarta yang teridentifikasi sebagai C. sorokiniana. Sebagai outgroup digunakan sequence $\mathrm{rbcL}$ dari Nannochloropsis gaditana. Analisis filogenetik menunjukkan bahwa lima isolat C. vulgaris tergabung menjadi satu clade dan terpisah dengan spesies $\mathrm{C}$. sorokiniana dari Yogyakarta.
\end{abstract}

[Kata kunci: mikroalga hijau, identifikasi molekuler, pohon kekerabatan, $r b c L]$

\footnotetext{
${ }^{*}$ correspondence author: fauziatul.fitriyah.91@ @mail.com
}

\begin{abstract}
Identifying the newly isolated species is crucial to establishing a reliable algal database with successful commercial applications for different biotechnological applications. Morphological identification does not give sufficient description, especially for tiny unicellular microalgae. The $r b c L$ gene encodes the large unit of ribulose-1, 5bisphosphate carboxylase /oxygenase (Rubisco) has been widely known for barcoding in plants and developed for microalgae molecular identification. In this study, we examined the local strains of green microalgae from Indonesia using the $r b c L$ partial gene sequence to identify the strains. Green microalgae isolates originated from Yogyakarta, Serayu, Gondol, Ancol, Cilegon, and Teluk Jakarta were cultured in $\mathrm{f} / 2$ media and harvested for DNA extraction. The DNA extracted was proceeded to PCR using 1AB_rbcL primer pair to amplify the sequences of $r b c \bar{L}$ gene with target band located at $582 \mathrm{bp}$, followed by the sequencing of the PCR product was conducted. Molecular identification of local green microalgae isolates was successfully carried out using primers $1 \mathrm{AB} \_$rbcL with a genetic similarity of $99 \%$ toward identified species in the NCBI database. Among six isolates, TJ, G, S, C, and A isolates were identified as C. pyrenoidosa. Only CP isolate from Yogyakarta identified as $C$. sorokiniana. Nannochloropsis gaditana rbcL sequence was selected as an outgroup. The phylogenetic analysis indicated that the five isolates of Chlorella belong to one clade and clearly distinguished from $C$. sorokiniana isolate from Yogyakarta.
\end{abstract}

[Keywords: green microalgae, molecular identification, phylogenetic tree, $r b c L]$

\section{Introduction}

Green microalgae (Chlorophytes), including Chlorophyceae are important producers of oxygen in aquatic seawater and freshwater, which are often 
used as bioindicators in waste water treatment, water monitoring, and ecological studies (Pasha et al., 2016). For decades, strains of Chlorella (Chlorophyceae, Chlorococcales) have served as model organisms in biochemical and plant physiology research. In addition, green microalgae have recently gained interest worldwide for biotechnological applications such as fuel, food, animal feed, and valuable chemical production (Khan et al., 2018). Recently, a member of Chlorophyceae, Chlorella variabilis gained more attention for the capacity to convert long-chain fatty acids to alkanes or alkenes in a lightdependent process (Huijbers et al., 2018).

The identification of green microalgae can be a pretty challenging task and often requires tedious microscopic examination of live cultured cells by a taxonomist (Hadi et al., 2016). Therefore, molecular identification provides a reliable solution to identify microalgae more accurately and faster to the species level (Yanuhar et al., 2019). DNA barcoding is an established technique for species identification, which identifies specimens based on DNA sequence similarity against a sequence database of previously identified species (Fei et al., 2020). This powerful technique has brought significant improvements to applications such as taxonomy, biosecurity, ecology, and food product regulation (Hadi et al., 2016). DNA-based identification is beneficial for microalgae species identification, which is crucial to establish a reliable algal database with successful commercial applications for different biotechnological applications (Ashour et al., 2019).

Potential Chlorophyta DNA barcodes have included chloroplast genes ( $r b c L, C p 23 S$, and tufA), nuclear genes (18S rDNA, nuITS1, and nuITS2), and mitochondrial DNA (COI) (Pawlowski et al., 2012). However, none of these markers were considered ideal for use across all lineages. The most commonly used DNA marker for Chlorophyta barcode is the $18 S \mathrm{rDNA}$ sequence. As a result, there are (as of 7 December 2020) 1495 18S rDNA sequences listed for Chlorella alone in Genbank (NCBI). Many researchers are using the $18 S \mathrm{rDNA}$ sequences as a DNA barcode for species identification. However $18 S$ rDNA is a highly conserved gene that is in general not considered appropriate for identification at the species level (Leliaert et al., 2012). Several species and varieties of green microalgae were initially characterized by the much more diverse $r b c L$ gene ( Suda et al., 2002; Fawley \& Fawley, 2007; Fawley et al., 2015). Recently, researchers have shown that strains with identical $18 S$ rDNA sequences can have considerable variation in the $r b c L$ gene (Wei et al., 2013; Carpinelli et al., 2014). Regardless of the unavailability of a universal PCR marker for DNA barcode, the $r b c L$ marker is considered a good marker for green algae (Hadi et al., 2016).
Over $60 \%$ of Indonesia's territory is covered by water (Rahman et al., 2019). To be one of the enormous diversities in the world, not all of those areas had been explored yet. This present study was undertaken to (1) identify green microalgae isolates that originated from several places in Indonesia by using $r b c L$ molecular markers as DNA barcodes, (2) construct a phylogenetic tree between species found in several places in Indonesia which previously analyzed by DNA barcoding.

\section{Materials and Methods}

\section{Microalgae strains}

Green microalgae originated from Yogyakarta (CP), Serayu (S), Gondol (G), Ancol (A), Cilegon (C), and Teluk Jakarta (TJ) were provided by the Laboratory of Bioindustry, Indonesian Research Institute for Biotechnology and Bioindustry (IRIBB). The microalgae were cultured with the inoculum amount (v/v) of $10 \%$ in $\mathrm{f} / 2$ liquid culture medium (Guillard \& Ryther, 1962) in sterile conditions at $21^{\circ} \mathrm{C}$ under the illumination of 800 1000 lux. The microalgae were cultivated in artificial seawater (Monsterlaut ASW Salt Mix) with the following $\mathrm{f} / 2$ nutrients (from stock solution): $0.25 \mathrm{~mL} \mathrm{NaNO} 3\left(75 \mathrm{~g} \mathrm{~L}^{-1}\right), 0.25 \mathrm{~mL}$ $\mathrm{NaH}_{2} \mathrm{PO}_{4}\left(5 \mathrm{~g} \mathrm{~L}^{-1}\right), 0.25 \mathrm{~mL} \mathrm{Na}_{2} \mathrm{CO}_{3}\left(30 \mathrm{~g} \mathrm{~L}^{-1}\right)$, $0.25 \mathrm{~mL}$ trace metal solution and $0.125 \mathrm{~mL}$ vitamins solution. Trace metal solution was prepared in pure water containing (per liter): 3.15 g $\mathrm{FeCl}_{3} \cdot 6 \mathrm{H}_{2} \mathrm{O} ; 4.36 \mathrm{~g} \mathrm{Na}$ EDTA $2 \mathrm{H}_{2} \mathrm{O} ; 0.1 \mathrm{~mL}$ $\mathrm{CuSO}_{4} \cdot 5 \mathrm{H}_{2} \mathrm{O}\left(9.8 \mathrm{~g} \mathrm{~L}^{-1}\right) ; 0.1 \mathrm{~mL} \mathrm{Na}_{2} \mathrm{MoO}_{4} \cdot 2 \mathrm{H}_{2} \mathrm{O}$ $\left(6.3 \mathrm{~g} \mathrm{~L}^{-1}\right) ; 0.1 \mathrm{~mL} \mathrm{ZnSO}_{4} \cdot 7 \mathrm{H}_{2} \mathrm{O}\left(22 \mathrm{~g} \mathrm{~L}^{-1}\right) ; 0.1 \mathrm{~mL}$ $\mathrm{CoCl}_{2} \cdot 6 \mathrm{H}_{2} \mathrm{O}\left(10 \mathrm{~g} \mathrm{~L}^{-1}\right) ; 0.1 \mathrm{~mL} \mathrm{MnCl}{ }_{2} \cdot 4 \mathrm{H}_{2} \mathrm{O}(180$ $\left.\mathrm{g} \mathrm{L}^{-1}\right)$. The vitamin solution was prepared in pure water containing (per liter): $40 \mathrm{~mL}$ thiamine $\mathrm{HCl}$ (0.05 $\left.\mathrm{g} \mathrm{L}^{-1}\right), 1 \mathrm{~mL}$ biotin (vitamin $\left.\mathrm{H}\right)\left(0.1 \mathrm{~g} \mathrm{~L}^{-1}\right)$, and $0.1 \mathrm{~mL}$ cyanocobalamin $\left(0.1 \mathrm{~g} \mathrm{~L}^{-1}\right)$. Cells of microalgae isolates were collected at the exponential growth at five days culture with centrifugation $10.000 \mathrm{rpm}$ for $5 \mathrm{~min}$ and then transferred to $2 \mathrm{~mL}$ microtubes.

\section{DNA extraction}

DNA extraction and molecular analysis were conducted at Biochemistry and Biomolecular Laboratory, IRIBB. The DNA was extracted with the CTAB method described previously by Orozco-Castillo et al. (1994) and modified by Budiani et al. (2016) with supplementation of $1 \%$ $\beta$-mercaptoethanol into the lysis buffer. The CTAB lysis buffer was added $(500 \mu \mathrm{l})$ into the sample and then agitated using vortex (without grinding) and incubated for $30 \mathrm{~min}$ at $65^{\circ} \mathrm{C}$. DNA were extracted with $500 \mu \mathrm{l}$ Chloroform-Isoamyl Alcohol and precipitated in Isopropanol. The amount and purity of extracted DNA was determined using Nanodrop 2000 (Thermo Scientific) spectrophotometer. The purity of extracted DNA was assessed by the absorbance (A) ratio of $260 \mathrm{~nm}$ and $280 \mathrm{~nm}$. 


\section{Amplification of the rbcL gene and sequencing}

The oligonucleotide primers 1AB_rbcL were amplified using modified forward primer 5'TCIGCIAARAACTAYGGTCG-3' and reverse primer 5'-GGCATRTGCCAIACRTGRAT-3 as described previously (Ghosh \& Love, 2011). This set of primers amplified DNA from Chlorophyta, Eglenozoa, and certain bacteria, including Cyanobacteria with a product size $\sim 615 \mathrm{bp}$. The PCR protocol included an initial denaturation of 3 min at $95{ }^{\circ} \mathrm{C}$ followed by 40 cycles of $1 \mathrm{~min}$ at 95 ${ }^{\circ} \mathrm{C}, 1 \mathrm{~min}$ at $55^{\circ} \mathrm{C}$ and $1 \mathrm{~min} 30 \mathrm{~s}$ at $72{ }^{\circ} \mathrm{C}$, and a 15 min $72{ }^{\circ} \mathrm{C}$ of final extension step. The PCR products were visualized on $0.8 \%$ agarose gel electrophoresis stained by GreenSafe DNA Gel Stain (Canvax Biotech). The purified DNA was commercially sequenced (First Base Lab, PT. Genetika Science) using Applied Biosystems ${ }^{\mathrm{TM}}$ BigDye $^{\text {TM }}$ Terminator v3.1 Cycle Sequencing Kit with the same forward and reverse primer used in the PCR process.

\section{Molecular data analysis}

Computer-assisted sequence analysis and assembly were performed in Geneious Prime Software. Each consensus sequence measured in this study was Basic Local Alignment Search Tool (BLAST) against the sequence in the Genbank database in NCBI. The percentage of identical sites was being evaluated. The phylogenetic analysis was carried out by constructing the neighborjoining tree with Tamura-Nei distances. Nannochloropsis gaditana was selected as an outgroup (Tamura \& Nei, 1993). A phylogenetic test using the Bootstrap method (1,000 replicates) was used.

\section{Results and Discussion}

\section{DNA extraction and molecular identification}

Genomic DNA of six isolates originated from Teluk Jakarta (TJ), Gondol, Cilegon, Serayu, Ancol, and Yogyakarta (Indonesia) were extracted and quantified with spectrophotometry analysis. Table 1 showed the concentration of DNA extracted and the purity of each sample. The result indicated that DNA concentrations for all isolates are considered enough. PCR requires 1-1000 ng $\left(10^{4}-10^{7}\right.$ molecules) of DNA template, generally for a $25 \mu \mathrm{l}$ PCR reaction, 50-125 ng of genomic DNA will be required (Lorenz, 2012). All extracted samples by the ratio of A260/A280 indicate good purity. However, the ratio of A260/A230 was too low, indicating that absorb at $230 \mathrm{~nm}$, such as EDTA from the culture media or carbohydrates from the cell extract (NanoDrop Inc., 2007).

The extracted DNA of CP seemed unreasonably too high with high viscosity, making it difficult to pipette. For quality check, CP genomic DNA was then run in agarose gel electrophoresis, and the result was shown in Figure 1. The genomic DNA of CP isolates present in a similar size to lambda DNA Marker around 48.5 $\mathrm{kbp}$. However,the visualization was a faint band that may indicate low DNA amount, with a bright smear at the bottom of agarose gel due to high RNA contamination. DNA quality and purity will have a substantial effect on a successful PCR experiment. DNA extraction contaminants are common inhibitors in PCR and should be carefully avoided. Common DNA extraction inhibitors of PCR, including RNA, salts, and detergents, in all probability, will be problematic for PCR (Lorenz, 2012).

The PCR reaction and visualization were carried out to verify that the microalgae strains belong to the Chlorophyta using general primer for green microalgae. The PCR results of the six isolates using the $r b c L$ gene showed an amplified band with a length of $~ 615$ bp (Figure 1). DNA sequences from forward and reverse direction were trimmed by an error probability limit of $5 \%$ in Geneious Prime software. Each sequence pair was de novo assembled to create a consensus sequence and then analyzed using nucleotide BLASTn to see the query sample homology with microalgae species in the nucleotide collection (nr/nt) database. The sequences were also submitted to BOLD for comparison of species identification against Genbank (Table 2).

Table 1. Concentration and purity of extracted DNA

Tabel 1. Konsentrasi dan kemurnian DNA yang diekstrak

\begin{tabular}{|c|c|c|c|}
\hline $\begin{array}{l}\text { Sample ID } \\
\text { ID sampel }\end{array}$ & $\begin{array}{c}\text { DNA Concentration }\left(\mathrm{ng} \mu \mathrm{l}^{-1}\right) \\
\text { Konsentrasi DNA }\left(\mathrm{ng} \mu \mathrm{l}^{-1}\right)\end{array}$ & $\begin{array}{l}\text { A260/A280 ratio } \\
\text { Rasio A260/A280 }\end{array}$ & $\begin{array}{l}\text { A260/A230 ratio } \\
\text { Rasio A260/A230 }\end{array}$ \\
\hline $\mathrm{CP}$ & 453.8 & 1.87 & 1.77 \\
\hline $\mathrm{S}$ & 171.3 & 1.88 & 1.35 \\
\hline $\mathrm{G}$ & 153.6 & 1.74 & 1.04 \\
\hline A & 49.9 & 1.84 & 1.02 \\
\hline $\mathrm{C}$ & 54.1 & 1.92 & 1.76 \\
\hline $\mathrm{TJ}$ & 50.0 & 1.82 & 1.08 \\
\hline
\end{tabular}

Note: $\mathrm{CP}=$ Yogyakarta isolate, $\mathrm{S}=$ Serayu isolate, $\mathrm{G}=\mathrm{Gondol}$ isolate, $\mathrm{A}=$ Ancol isolate, $\mathrm{C}=\mathrm{Cilegon}$ isolate, $\mathrm{TJ}=\mathrm{Teluk} \mathrm{Jakarta}$ isolate Keterangan: $C P=$ isolat Yogyakarta, $S=$ isolat Serayu, $G=$ isolat Gondol, $A=$ isolat Ancol, $C=i$ solat Cilegon, TJ= isolat Jakarta 


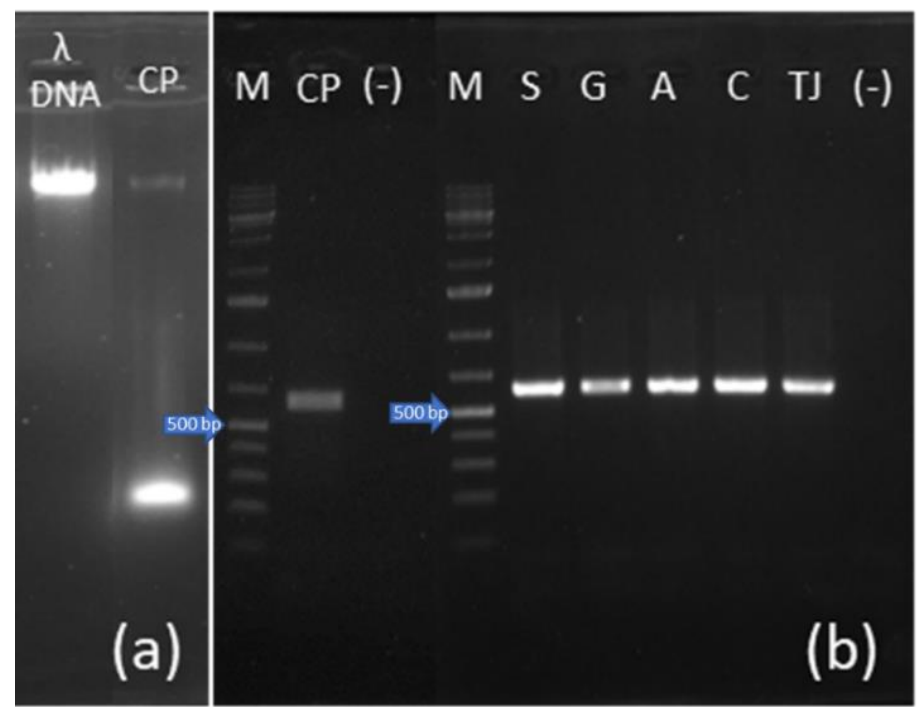

Figure 1. Visualization of (a) quality check of CP genomic DNA against lambda DNA marker and (b) PCR amplification of six isolates using the $r b c L$ gene at $615 \mathrm{bp}$. M=1kb+ DNA marker, (-) = negative control $(\mathrm{NFW}), \mathrm{CP}=$ Yogyakarta isolate, $\mathrm{S}=$ Serayu isolate, $\mathrm{G}=\mathrm{Gondol}$ isolate, $\mathrm{A}=\mathrm{Ancol}$ isolate, $\mathrm{C}=$ Cilegon isolate, $\mathrm{TJ}=$ Teluk Jakarta isolate

Gambar 1. Visualisasi (a) pengecekkan kualitas DNA genom CP terhadap lambda DNA dan (b) hasil amplifikasi dengan $P C R$ dari enam isolat menggunakan gen rbcL pada $615 \mathrm{bp} . M=1 \mathrm{~kb}+$ DNA marker, $(-)=$ Kontrol negatif $(N F W), C P=$ isolat Yogyakarta, $S=$ isolat Serayu, $G=$ isolat Gondol, $A=$ isolat Ancol, $C=$ isolat Cilegon, $T J=$ isolat Teluk Jakarta

Table 2. Species identification based on BLASTn and BOLD system v4 analysis

Tabel 2. Identifikasi spesies berdasarkan analisis di BLASTn dan BOLD system $v 4$

\begin{tabular}{|c|c|c|c|c|c|c|}
\hline \multirow{3}{*}{$\begin{array}{l}\text { Isolates } \\
\text { Isolat }\end{array}$} & \multicolumn{3}{|c|}{$\begin{array}{c}\text { BLAST-NCBI } \\
B L A S T-N C B I\end{array}$} & \multicolumn{3}{|c|}{$\begin{array}{l}\text { BOLD system v4 } \\
\text { BOLD system } v 4\end{array}$} \\
\hline & Species & Similarity & E-value & Species & Similarity & E-value \\
\hline & Spesies & Kemiripan & Skor-E & Spesies & Kemiripan & Skor-E \\
\hline $\mathrm{CP}$ & Chlorella sorokiniana & 94.70 & 0 & Chlorella sorokiniana & 95.55 & 0 \\
\hline S & Chlorella pyrenoidosa & 99.36 & 0 & Dicloster acuatus & 92.65 & 0 \\
\hline G & Chlorella pyrenoidosa & 99.36 & 0 & Dicloster acuatus & 92.64 & 0 \\
\hline A & Chlorella pyrenoidosa & 99.51 & 0 & Dicloster acuatus & 92.88 & 0 \\
\hline $\mathrm{C}$ & Chlorella pyrenoidosa & 99.04 & 0 & Dicloster acuatus & 92.33 & 0 \\
\hline $\mathrm{TJ}$ & Chlorella sp. & 99.04 & 0 & Dicloster acuatus & 92.33 & 0 \\
\hline
\end{tabular}

Note: $\mathrm{CP}=$ Yogyakarta isolate, $\mathrm{S}=$ Serayu isolate, $\mathrm{G}=\mathrm{Gondol}$ isolate, $\mathrm{A}=\mathrm{Ancol}$ isolate, $\mathrm{C}=$ Cilegon isolate, $\mathrm{TJ}=$ Teluk Jakarta isolate Keterangan: $C P=$ isolat Yogyakarta, $S=$ isolat Serayu, $G=$ isolat Gondol, $A=$ isolat Ancol, $C=$ isolat Cilegon, $T J=$ isolat Teluk Jakarta

The base sequence homology analysis of five isolates (TJ, G, C, S, and A) showed a high level of up to $99 \%$. The query cover varies between $96-$ $100 \%$ and an E-value of 0.0 (Table 2). Based on the BLASTn analysis and phylogenetic tree construction of prior species in the database, TJ isolate was identified as Chlorella sp. The C, AS, $\mathrm{G}, \mathrm{A}$, and $\mathrm{C}$ isolates were identified as $C$. pyrenoidosa. Only CP isolate from Yogyakarta showed a moderate homology level of $94.57 \%$, with a query cover of $95 \%$ with $C$. sorokiniana MK842150.1. In line with the previous study, a homology level of $99-100 \%$ and the E-value is smaller than e-0.4 from BLASTn defined as identical and identified as the species (Yanuhar et al., 2019). Yanuhar et al. (2019) identified local green microalgae isolate as $C$. vulgaris using $r b c L$ gene sequence. The sequence homology analysisshows homology of $99 \%$ of 589 bases and an E-value of 0.0 .

Chromatogram of CP sequence also shown to have a low quality compared to another sequence (data not shown). The $r b c L$ sequence of $\mathrm{CP}$ isolate has a pretty low base call quality, by Phred quality score below 20 throughout the reverse direction sequence and on the upstream and downstream of forward direction sequence. A Phred quality score is a measure of the quality of identifying the nucleobases generated by automated DNA sequencing (Shi et al., 2016). A Phred Score of 20 is acceptable, which means that whatever it qualifies is $99 \%$ accurate with a $1 \%$ chance of error 
and is just as valuable as one sequence with a quality score above 40 (error probability of 1 in 10,000) (Richterich, 1998). Besides, there are many multi-peaks (data not shown), which also contribute to the low base call quality. The primary cause of multi-peaks in the sequence data is a contamination of the culture or specimen with other living organisms or genetic material. Low base call quality may contribute to the low homology level compared to other isolates.

The plastid-encoded $r b c L$ gene has been widely used for DNA barcoding in green microalgae. This gene is a part of the DNA sequence located in cpDNA. It is considered standard DNA barcoding markers in the plant due to their universality, relatively high overall sequence quality, low cost, and high discrimination (Carneiro et al., 2019). The $r b c L$ gene also provides many characters to study phylogenetic because it has a total length of 1400 bp (Basith, 2015). This sequence has a low level of mutation compared with other barcodes in cpDNA, with high similarity between species (Sundari \& Papuangan, 2019).

Saputro et al. (2019) isolated microalgae from 3 different stations of Wonorejo river estuary, Surabaya, East Java, Indonesia, and identified eight isolates as Mycrocystis sp., Nostoc sp., Chlorella sp., Tabellaria, Synedra, Nitzschia, Navicula, and Closteriopsis using rbcL gene as the molecular marker (Saputro et al., 2019). However, genuinely universal primers are not available for $r b c L$, although some primers can be used on a wide range of taxa (Hall et al., 2010). A combination of morphological and molecular approaches may provide better understanding of species identification in microalgae.

\section{Phylogenetic tree analysis}

Construction of phylogenetic tree was performed on $r b c L$ gene sequences of Chlorella from Indonesia, including six Chlorella isolates from this study and collected sequence from literature and Genbank (Table 3). A total of 11 Chlorella isolates from Indonesia were aligned with Nannochloropsis gaditana's $r b c L$ gene sequence using Geneious Alignment Program with cost matrix at $65 \%$ similarity. Alignment of 12 sequences was then used to construct phylogenetic tree with Tamura-Nei genetic distance mode and the NeighborJoining Tree method.

According to the phylogenetic tree, these strains were grouped into five clusters. Based on the phylogenetic tree in Figure 3, it was found that the Chlorella strains (G, S, C, TJ, and A) were clustered in the same clade with high genetic similarity between strains of up to $99 \%$, except between Chlorella sp. strain Teluk Jakarta (TJ) and C. pyrenoidosa strain Cilegon (C) which has similarity level at $98.98 \%$ (Table 4). These high genetic similarities showed that a DNA "barcoding gap" did not exist in the $r b c L$ gene between $\mathrm{G}, \mathrm{S}$, $\mathrm{C}, \mathrm{TJ}$, and A strains, indicating that Chlorella sp. strain TJ fall into the same species of $C$. pyrenoidosa. Therefore, all of these five isolates originated from quite distant region, especially $C$. pyrenoidosa strain $\mathrm{G}$, which originated from different Bali island. In contrast, others were distributed in Western and Central Java. The bootstrap value between branches is also moderately high $(72.1 \%)$, which supports that these strains come from a different population. This result proved how wide the distribution of this species, from West Java to Bali.

Chlorella sorokiniana strain Yogyakarta (CP) fell into a distinct cladeconsistent with the taxonomic assignments. In comparison, the construction of phylogenetic of four priors Chlorella sp. datasets from Genbank formed into three different clades, which indicated that they come from a different population. Whereas, $C$. vulgaris strain Situbondo clustered in the same clade with Chlorella sp. MH048633 indicated these have closer lineage but come from different population as seen by the bootstrap value of $72.4 \%$.

Table 3. Sequences of $r b c L$ gene in microalgae used for phylogenetic tree construction

Tabel 3. Sekuens gen rbcL dari microalgae yang digunakan dalam konstruksi pohon kekerabatan

\begin{tabular}{|c|c|c|c|}
\hline $\begin{array}{l}\text { Species } \\
\text { Spesies }\end{array}$ & $\begin{array}{c}\text { Accession Number } \\
\text { Nomor aksesi }\end{array}$ & $\begin{array}{l}\text { Origin } \\
\text { Asal }\end{array}$ & $\begin{array}{c}\text { Reference } \\
\text { Sumber pustaka }\end{array}$ \\
\hline Nannochloropsis gaditana & AB052735.1 & Capetown, South Africa & Genbank \\
\hline Chlorella sp. & MH048635 & Indonesia ocean & Genbank \\
\hline Chlorella sp. & MH048634 & Indonesia ocean & Genbank \\
\hline Chlorella sp. & MH048633 & Indonesia ocean & Genbank \\
\hline Chlorella sp. & MH048632 & Indonesia ocean & Genbank \\
\hline Chlorella vulgaris & - & Situbondo, Indonesia & (Yanuhar et al., 2019) \\
\hline Chlorella sorokiniana & - & Yogyakarta, Indonesia & This study \\
\hline Chlorella pyrenoidosa & - & Gondol, Indonesia & This study \\
\hline Chlorella pyrenoidosa & - & Serayu, Indonesia & This study \\
\hline Chlorella pyrenoidosa & - & Cilegon, Indonesia & This study \\
\hline Chlorella sp. & - & Teluk Jakarta, Indonesia & This study \\
\hline Chlorella pyrenoidosa & - & Ancol, Indonesia & This study \\
\hline
\end{tabular}




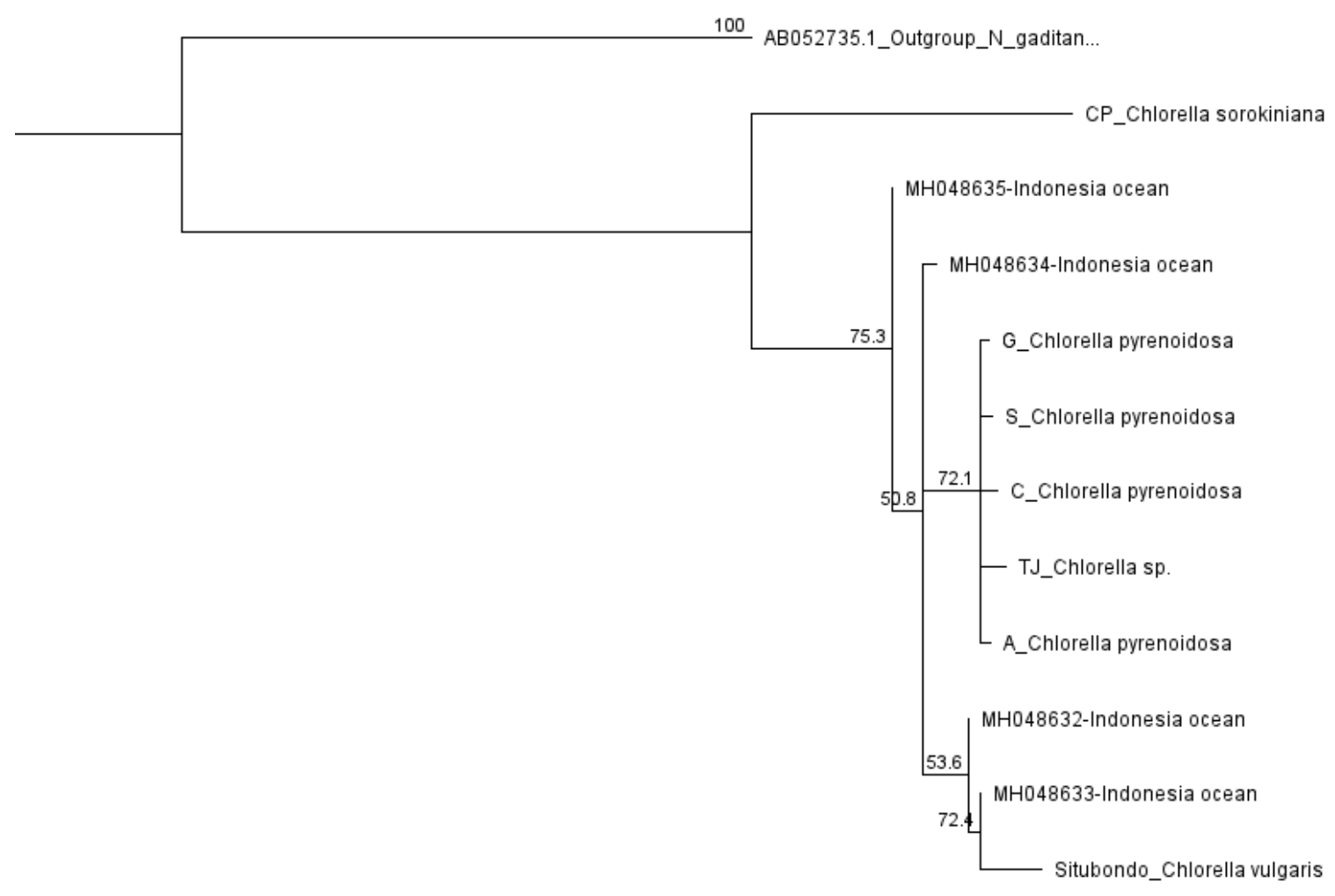

Figure 3. Neighbour-Joining (NJ) phylogenetic tree based on $r b c L$ gene of local Chlorella strains from Indonesia. The tree was constructed by the neighbor-joining (NJ) method in the Geneious Prime software based on the multiple sequence alignment by Geneious alignment program. Bootstrap support values of 1000 replicates (\%) are shown at the nodes

Gambar 3. Pohon kekerabatan Neighbour-Joining (NJ) berdasarkan gen rbcL strain lokal Chlorella dari Indonesia. Pohon disusun dengan metode neighbor-joining (NJ) dalam software Geneious Prime berdasarkan multiple sequence alignment oleh Geneious alignment program. Bootstrap support values sebanyak 1000 ulangan (\%) ditampilkan pada percabangan

Table 4. Genetic similarity matrix among local Chlorella strains Tabel 4. Matriks kekerabatan genetik antar strain Chlorella local

\begin{tabular}{|c|c|c|c|c|c|c|c|c|c|c|c|c|}
\hline Strain & $\mathrm{TJ}$ & Cv Sit. & $\mathrm{S}$ & MH-35 & MH-34 & MH-33 & MH-32 & G & $\mathrm{CP}$ & C & A & $\mathrm{Nga}$ \\
\hline $\mathrm{TJ}$ & & 92.86 & 99.44 & 98.06 & 98.06 & 98.06 & 98.06 & 99.12 & 86.19 & 98.98 & 99.12 & 63.44 \\
\hline Cv Sit. & & & 94.74 & 99.04 & 99.36 & 99.42 & 99.42 & 92.98 & 77.68 & 91.38 & 91.38 & 66.05 \\
\hline S & & & & 99.04 & 99.04 & 99.04 & 99.04 & 99.52 & 86.19 & 99.60 & 99.44 & 63.85 \\
\hline MH-35 & & & & & 99.72 & 99.72 & 99.72 & 98.08 & 84.47 & 97.14 & 97.14 & 71.39 \\
\hline MH-34 & & & & & & 100.00 & 100.00 & 98.08 & 84.47 & 97.14 & 97.14 & 71.39 \\
\hline MH-33 & & & & & & & 100.00 & 98.08 & 84.47 & 97.14 & 97.14 & 70.26 \\
\hline MH-32 & & & & & & & & 98.08 & 84.47 & 97.14 & 97.14 & 70.26 \\
\hline $\mathrm{G}$ & & & & & & & & & 86.23 & 99.24 & 99.36 & 63.67 \\
\hline $\mathrm{CP}$ & & & & & & & & & & 86.35 & 85.95 & 63.97 \\
\hline $\mathrm{C}$ & & & & & & & & & & & 99.36 & 62.52 \\
\hline A & & & & & & & & & & & & 63.93 \\
\hline $\mathrm{Nga}$ & & & & & & & & & & & & \\
\hline
\end{tabular}

Note: $\mathrm{CP}=$ Yogyakarta isolate, $\mathrm{TJ}=$ Teluk Jakarta isolate, $\mathrm{G}=\mathrm{Gondol}$ isolate, $\mathrm{C}=$ Cilegon isolate, $\mathrm{S}=$ Serayu isolate, $\mathrm{A}=\mathrm{Ancol}$ isolate, $\mathrm{Cv}$ Sit=Chlorella vulgaris strain Situbondo, MH-35=Chlorella sp. MH048635, MH-34=Chlorella sp. MH048634, MH-33=Chlorella sp. MH048633, MH-32=Chlorella sp. MH048632, Nga=Nannochloropsis gaditana

Keterangan: TJ=isolat Teluk Jakarta, G=isolat Gondol, $C=i s o l a t$ Cilegon, $S=i$ solat Serayu, A= isolat Ancol, CP=isolat Yogyakarta, Cv Sit=Chlorella vulgaris strain Situbondo, $M H-35=$ Chlorella sp. $M H 048635, M H-34=$ Chlorella sp. $M H 048634, \quad M H-$ 33=Chlorella $s p$. $M H 048633, M H-32=$ Chlorella $s p$. $M H 048632$, Nga=Nannochloropsis gaditana 
The phylogeny helps combine knowledge of biological diversity for structural classifications and generate insight into the diversity and distribution (Leaché, 2013). Based on the constructed phylogenetic tree, genetic relations of species within the population and between populations can be recognized. Phylogenetic reconstruction performed by Prehadi et al. (2015) showed that the analysis was helped in the distribution analysis of shark landed in Muncar. They found that Carcharhinus brevipinna landed in Muncar was divided into two clades with the high bootstrap value indicated that these individuals might come from different populations.

The phylogenetic tree also better understands the taxonomy and describes the evolutionary lineage of species, organisms, or one distinct ancestor. Rahman et al. (2019) conducted a phylogenetic analysis of microalgae isolated from Wakatobi Marine National Park, Indonesia. The BLAST result of $18 S$ DNA sequences showed that the isolated microalgae strain was closest to Chlorella sp. KMCC 185 with a similarity of $99 \%$ and the query cover of $99 \%$. Therefore, the phylogenetic analysis showed the correlation of isolated strain with other species from Chlorella genus, which has no flagella, no mucilage, and eyespot. Based on the morphological, physiological, and phylogenetic analysis of the isolated microalgae, the isolate belongs to Chlorella volutis.

\section{Conclusion}

Six local microalgae isolates from different places in Indonesia were identified based on the rbcL gene. Microalgae strain TJ, G, S, C, and A isolates were identified as $C$. pyrenoidosa. Only $\mathrm{CP}$ isolate from Yogyakarta identified as $C$. sorokiniana. The phylogenetic analysis indicated that the five isolates of Chlorella belong to the same clade and are separated to $C$. sorokiniana isolate from Yogyakarta. It can be concluded that the $r b c L$ gene can be used as a DNA marker for molecular identification of species in the genus Chlorella.

\section{Acknowledgments}

This research was funded by Palm Oil Fund Management Agency as part of the research grant contract number PRJ-18/DPKS/2020.

\section{References}

Ashour M, ME Elshobary, R El-Shenody, AW Kamil \& AEF Abomohra (2019). Evaluation of a native oleaginous marine microalga Nannochloropsis oceanica for dual use in biodiesel production and aquaculture feed. Biomass Bioenergy 120, 439-447.

Basith A (2015). Peluang gen $r b c L$ sebagai DNA barcode berbasis DNA kloroplas untuk mengungkap keanekaragaman genetik padi beras hitam (Oryza sativa L.) lokal Indonesia. Seminar Nasional XII Pendidikan Biologi FKIP UNS, 938-941.

Budiani A, RA Putranto, H Minarsih, I Riyadi, Sumaryono \& B Abbas (2016). Kloning dan karakterisasi daerah promoter gen penyandi ADP glucose pyrophosphorylase dari Metroxylon sagu rendemen patitinggi dan rendah. Menara Perkebunan 84(1), 1-12.

Carneiro C, DM Moura, F Brambach, K Jair, H Bado, KV Krutovsky, H Kreft, SS Tjitrosoedirdjo, IZ Siregar \& O Gailing (2019). Integrating DNA barcoding and traditional taxonomy for the identification of Dipterocarps in remnant lowland forests of Sumatra. Plants 8(461), 1-14.

Carpinelli EC, A Telatin, N Vitulo, C Forcato, M D'Angelo, R Schiavon, A Vezzi, GM Giacometti, $T$ Morosinotto \& $G$ Valle (2014). Chromosome scale genome assembly and transcriptome profiling of Nannochloropsis gaditana in nitrogen depletion. Mol Plant 7(2), 323-335.

Fawley KP \& MW Fawley (2007). Observations on the diversity and ecology of freshwater Nannochloropsis (Eustigmatophyceae), with descriptions of new taxa. Protist 158(3), 325-336.

Fawley MW, I Jameson \& KP Fawley (2015). The phylogeny of the genus Nannochloropsis (Monodopsidaceae, Eustigmatophyceae), with descriptions of $N$. australis sp. Nov. and Microchloropsis gen. Nov. Phycologia 54(5), 545-552.

Fei C, S Zou, T Wang, C Wang, ND Kemuma, M He, SA Amin, \& C Wang (2020). A quick method for obtaining high-quality DNA barcodes without DNA extraction in microalgae. J Appl Phycol 32(2), 11651175 .

Ghosh S \& NG Love (2011). Application of $r b c L$ based molecular diversity analysis to algae in wastewater treatment plants. Bioresour Technol 102(3), 3619-3622.

Guillard RR \& JH Ryther (1962). Studies of marine planktonic diatoms. I. Cyclotella nana Hustedt, and Detonula confervacea (cleve) Gran. Can J Microbiol 8(1140), 229239.

Hadi SIIA, H Santana, PPM Brunale, TG Gomes, MD Oliveira, A Matthiensen, MEC Oliveira, FCP Silva \& BSAF Brasil (2016). DNA barcoding green microalgae isolated from neotropical inland waters. PLoS ONE 11(2), 
$1-18$.

Hall JD, K Fučíková, C Lo, LA Lewis \& KG Karol (2010). An assessment of proposed DNA barcodes in freshwater green algae. Cryptogamie, Algologie 31(4), 529-555.

Huijbers MME, W Zhang, F Tonin \& F Hollmann (2018). Light-Driven enzymatic decarboxylation of fatty acids. Angew Chem Int 57, 13648-13651.

Khan MI, JH Shin \& JD Kim (2018). The promising future of microalgae: current status, challenges, and optimization of a sustainable and renewable industry for biofuels, feed, and other products. Microb Cell Fact 17(36), 1-21.

Leaché AD (2013). phylogenetic trees made easy: a how-to manual by Barry G. Hall. $Q$ Rev Biol 88(1), 47-48.

Leliaert F, DR Smith, H Moreau, MD Herron, H Verbruggen, CF Delwiche \& O De Clerck (2012). Phylogeny and molecular evolution of the green algae. CRC Crit Rev Plant Sci $31(1), 1-46$.

Lorenz TC (2012). Polymerase chain reaction: Basic protocol plus troubleshooting and optimization strategies. J Vis Exp 63, 1-15.

NanoDrop Inc (2007). 260/280 and 260/230 Ratios NanoDrop ${ }^{\circledR} \quad$ ND-1000 and ND-8000 8Sample Spectrophotometers - Technical Support Bulletin T009. 8-9. http://www.bio.davidson.edu/projects/gcat/ protocols/NanoDrop_tip.pdf.

Orozco-Castillo C, KJ Chalmers, R Waugh \& W Powell (1994). Detection of genetic diversity and selective gene introgression in coffee using RAPD markers. Theor Appl Genet 87: 934-940.

Pasha F, S Saggu \& MF Albalawi (2016). Future perspectives of DNA barcoding in marine zooplanktons and invertebrates. In: $\mathrm{S}$ Trivedi, A A Ansari, SK Ghosh \& H Rehman (eds.), DNA Barcoding in Marine Perspectives: Assessment and Conservation of Biodiversity. Switzerland, Springer International Publishing p. 169-179.

Pawlowski J, S Audic, S Adl, D Bass, L Belbahri, C Berney, SS Bowser, I Cepicka, J Decelle, M Dunthorn, AM Fiore-Donno, GH Gile, M Holzmann, R Jahn, M Jirků, PJ Keeling, M Kostka, A Kudryavtsev, E Lara, J Lukes, DG Mann, EAD Mitchel, F Nitsche, M Romeralo, GW Saunders, AGB Simpson, AV Smirnov, JL Spouge, RF Stern, $T$ Stoeck, J Zimmermann, D Schindel, \& C de Vargas (2012). CBOL protist working group: barcoding eukaryotic richness beyond the animal, plant, and fungal kingdoms. PLoS Biol 10(11), 1-5.

Prehadi, A Sembiring, EM Kurniasih, Rahmad, D Arafat, B Subhan \& HH Madduppa (2015). DNA barcoding and phylogenetic reconstruction of shark species landed in muncar fisheries landing site in comparison with southern Java fishing port. Biodiversitas 16(1), 55-61.

Rahman DY, S Praharyawan, S Raharjo, F Fadiyah \& D Susilaningsih (2019). Morphology and molecular characterization of newly isolated microalgae strain Chlorella volutis LIPI13WKT066 from Wakatobi Islands and its potential use. Ann Bogor 23(1), 13-19.

Richterich P (1998). Estimation of errors in "raw" DNA sequences: a validation study. Genome Res 8(3), 251-259.

Saputro TB, KI Purwani, D Ermavitalini \& AF Saifulloh (2019). Isolation of high lipid content microalgae from wonorejo river, Surabaya, Indonesia and its identification using $r b c L$ marker gene. Biodiversitas 20(5), 1380-1388.

Shi H, W Li \& X Xu (2016). Learning the comparing and converting method of sequence phred quality score. In: Proceedings of the $6^{\text {th }}$ International Conference on Management, Education, Information and Control (MEICI 2016). Shenyang, China. p, 260-263.

Suda S, M Atsumi \& H Miyashita (2002). Taxonomic characterization of a marine Nannochloropsis species, N. oceanica sp. nov. (Eustigmatophyceae). Phycologia 41(3), 273-279.

Sundari N \& N Papuangan (2019). Amplification and analysis of $\mathrm{Rbcl}$ gene (Ribulose-1,5Bisphosphate Carboxylase) of clove in Ternate island. IOP Conf. Series: Earth and Environmental Science, 276, 1-7.

Tamura K \& M Nei (1993). Estimation of the number of nucleotide substitutions in the control region of mitochondrial DNA in humans and chimpanzees. Mol Biol Evol 10(3), 512-526.

Wei L, Y Xin, D Wang, X Jing, Q Zhou, X Su, J Jia, K Ning, F Chen, Q Hu \& J Xu (2013). Nannochloropsis plastid and mitochondrial phylogenomes reveal organelle diversification mechanism and intragenus phylotyping strategy in microalgae. $B M C$ Genomics 14,1-17.

Yanuhar U, NR Caesar \& M Musa (2019). Identification of local isolate of microalgae Chlorella vulgaris using Ribulose-1,5- 
Molecular identification and phylogenetic analysis of Chlorella isolates using rbcL gene......(Fitriyah et al.)

Bisphosphate Carboxylase/Oxygenase large subunit $(r b c L)$ Gene. IOP Conf. Series: Materials Science and Engineering 546, 16. 